\title{
Penerapan Analitycal Hirarchi Process (AHP) dalam Sistem Penilaian Kinerja Karyawan Sebagai Acuan Untuk Promosi Jabatan Di PT. XYZ.
}

\author{
Agustian Suseno ${ }^{1}$, Sutrisno ${ }^{2}$ \\ 1,2 Teknik Industri Universitas Singaperbangsa Karawang \\ Jln. H.S Ronggo Waluyo Teluk Jambe., Kab. Karawang, Jawa Barat \\ ${ }^{1}$ susenoagustian@gmail.com
}

Dikirimkan: 03, 2019. Diterima: 07, 2019. Dipublikasikan: 12, 2019

\begin{abstract}
Improved performance at PT. XYZ is very much determined by its human resource capabilities. In fact, the ability of existing resources sometimes cannot be utilized optimally. This can be seen from the high and low performance intended by the employees. One of the causes of not optimal employee performance is due to performance appraisals and awards that are not as expected. This dissatisfaction occurs due to the existence of a work appraisal system and a closed, directional and subjective reward system. Method that use in studi in this case is Analytical Hirarchi Process (AHP), were do prioritas to factor-factor which eight (8) Criteria Performance to work employee that is : knowledge, honesty and Effort, Initiative, Discipline, loyalitas, work responsibility, cooperation and the leader. For can to determine we can to do in todecide prioritas for that, before doit we must make structur hirarci from criteria - criteria wich acurate because that important to decide prioritas from factor - factor wich to influence criteria - criteria Performance from employee. Fundation from resutl calculation Analytical Hirarchi Precess (AHP) beable to factor - factor wich prioritas by: part each grade is for to :each operational / grade 1- 4 criteria knowledge wich most big, with heavy 0,190, for each Administasi / grade $5-7$ criteria knowledge that most big with heavy 0,175, for each manajerial / grade 8 - 11 criteria wich most big is aleasder with heavy 0,156. Thus, the company is expected to be able to find out the factors that must be prioritized from each part/grade to be assessed so that with the presence of priority levels, employees can improve their performance in accordance with company expectations.
\end{abstract}

Keywords - Analytical Hirarchi Process (AHP); Criteria Performance to work employee;Grade

\begin{abstract}
Abstrak - Peningkatan kinerja di PT. XYZ sangat ditentukan oleh kemampuan sumber daya manusia yang dimilikinya. Pada kenyataannya kemampuan sumber daya yang ada tersebut kadang tidak dapat dimanfaatkan secara optimal. Hal ini terlihat dari tinggi rendahnya kinerja yang ditujukan oleh para karyawan. Salah satu penyebab tidak optimalnya kinerja karyawan adalah karena adanya penilaian kinerja dan penghargaan yang tidak sesuai dengan yang diharapkan mereka. Ketidakpuasan ini terjadi akibat adanya sistem penilaian kerja dan sistem penghargaan yang tertutup, searah dan bersifat subjektif. Metode yang digunakan dalam studi kasus ini adalah Analitycal Hirarchi Process (AHP) dimana melakukan prioritas terhadap faktor - faktor yang mempengaruhi delapan (8) kriteria penilaian kinerja karyawan diantaranya yaitu : pengetahuan, Inisiatif, disiplin, kejujuran dan usaha, kerjasama, tanggung jawab, loyalitas dan kepemimpinan. Untuk dapat memastikan bahwa kita dapat melakukan dalam menentukan prioritas tersebut maka sebelumnya dilakukan terlebih dahulu pembentukan struktur hirarki dari kriteria - kriteria yang akan diteliti. oleh karena itu maka dilakukan penentuan prioritas terhadap faktor - faktor yang mempengaruhi kriteria - kriteria penilaian kinerja karyawan. Berdasarkan hasil dari perhitungan Analytical Hirarchi Process (AHP) didapatkan faktor - faktor yang diprioritaskan oleh bagian masing - masing grade / golongan yaitu : Bagian operasional/Grade 1-4 kriteria pengetahuan yang mendominasi paling besar dengan bobot 0,190 , Bagian administrasi/Grade 5-7 kriteria pengetahuan yang mendominasi paling besar dengan bobot 0,175 , Bagian manajerial/Grade 8-11 kriteria kepemimpinan yang mendominasi paling besar dengan bobot 0,156. Dengan demikian diharapkan perusahaan dapat mengetahui faktor - faktor yang harus diprioritaskan dari tiap-tiap bagian/grade yang akan dinilai.sehingga dengan adanya tingkat prioritas, karyawan dapat meningkatkan kinerjanya yang sesuai dengan harapan perusahaan.
\end{abstract}


Kata kunci-Analitycal Hirarchi Process (AHP); kriteria penilaian kinerja karyawan; Grade

\section{PENDAHULUAN}

Dasarnya arus globalisasi yang ditandai dengan Era Revolusi Industri 4.0 mengakibatkan terjadinya persaingan ketat antara organisasi perusahaan untuk memperebutkan posisinya. Persaingan tersebut merupakan tantangan bagi perusahaan untuk memiliki keunggulan bersaing. Salah satu yang yang dapat dijadikan keunggulan bersaing dan merupakan kompetensi yang dimiliki perusahaan.

Salah satu yang yang dapat dijadikan keunggulan bersaing dan merupakan kompetensi yang dimiliki perusahaan adalah peningkatan sumber daya manusia menjadi sumber daya yang profesional. Disamping itu, setiap orang dalam organisasi berusaha untuk mendapatkan kedudukan yang layak yang dapat menjamin kehidupannya. Namun tidak semua orang dapat mamperolehnya, sehingga tetrjadi persaingan diantara para karyawan untuk memenuhi harapannya. Hal ini juga dapat menjadi tantangan bagi perusahaan, dimana perusahaan harus dapat mengatur segalanya agar tidak terjadi konflik yang merugikan perusahaan.

Dalam peningkatan kualitas dan profesionalisme tersebut, perusahaan harus berusaha memanfaatkan sumber daya manusia yang dimilikinya. Peningkatan kualitas sumber daya tersebut dapat tercapai bila perusahaan mampu mengenali kemampuan sumber daya yang dimilikinya. Perusahaan akan lebih mudah mengambil keputusan jika mengetahui kinerja para karyawan. Penilaian kinerja perlu dilakukan untuk mengenali, mengukur dan mengembangkan kinerja karyawan. Perusahaan dapat mengambil keputusan untuk melakukan promosi, demosi, PHK, mengalokasikan kemampuan karyawan yang dimilikinya ataupun memilih karyawan untuk training dan pelatihan.

Melihat adanya masalah tersebut diatas, maka perlu adanya upaya manajemen untuk meningkatkan produktivitas perusahaan secara efisien dan efektif dengan mengoptimalkan kemampuan sumber daya manusia yang ada. Upaya yang dapat dilakukan perusahaan adalah dengan cara memotivasi para karyawannya agar dapat meningkatkan kemampuannya. Salah satunya yaitu melalui penilaian kinerja karyawan yang objektif yang dapat memberikan umpan balik kepada karyawan sehingga para karyawan merngetahui kelemahan dan kelebihan yang dimilikinya.

Disamping itu, dalam perusahaan juga sering timbul masalah ketidakpuasan para karyawan atas penghargaan yang diberikan perusahaan sebagai imbalan dari prestasi kerjanya. Hal ini terlihat dari adanya demonstrasi para karyawan yang menuntut kenaikan upah gaji atau penghargaan yang layak. Oleh karena itu, sebagai umpan balik atas keberhasilan karyawan maka perlu adanya sistem pemberian penghargaan yang sesuai dengan kinerja para karyawan. Sistem penghargaan ini akan memberikan motivasi dan kepuasan sebagai para karyawan, sehingga mereka dapat bekerja dengan baik sesuai sasaran yang ingin dicapai perusahaan. Hal ini secara tidak langsung dapat meningkatkan kinerja perusahaan.

\section{Metodologi PENELITIAN}

Analytic Hirarchi Process (AHP) merupakan model yang akan penulis gunakan dalam memecahkan masalah. AHP adalah suatu metode penentuan urutan (prioritas) dalam analisis multi kriteria yang sederhana dan fleksibel. AHP juga dapat menampung kreativitas pengambilan keputusan dalam membuat rancangan penyelesaian suatu masalah.

Peralatan utama dalam metode AHP ini adalah sebuah hirarki menggunakan persepsi manusia sebagai input utamanya. Dengan metode ini suatu masalah yang kompleks dan tidak terstruktur dipecahkan ke dalam kelompokkelompok yang diatur dalam bentuk hirarki.

Adapun langkah-langkah pengolahan data dengan menggunakan metode AHP adalah sebagai berikut [1] :

1. Mendefinisikan masalah dan menentukan solusi yang diinginkan.

2. Membuat struktur hirarki yang diawali dengan tujuan umum, subtujuan-subtujuan kriteria dan kemungkinan-kemungkinan alternatif pada tingkat kriteria yang paling bawah.

3. Melakukan penyebaran kuesioner kepada responden yang terpilih. Hasil dari pada kuesioner dimasukan ke dalam matriks perbandingan berpasangan yang telah disiapkan.

4. Membuat matrik perbandingan berpasangan yang menggambarkan kontribusi relatif atau pengaruh setiap elemen terhadap masingmasing tujuan atau kriteria yang setingkat diatasnya, perbandingan dilakukan berdasarkan "jugment" dari pengambil keputusan dengan menilai tingkat kepentingan suatu elemen dibandingkan dengan elemen yang lainnya.

5. Melakukan perbandingan berpasangan sehingga diperoleh judgment sebanyak $n \quad x$ $(\mathrm{n}-1) / 2$ buah dengan $\mathrm{n}$ adalah banyaknya elemen yang dibandingkan dengan elemen yang lainnya. 
6. Menghitung nilai eigen value dan menguji konsistensinya. Langkah-langkah yang dilakukan dalam tahap ini adalah :

a. Menghitung eigen value dari setiap baris dengan menggunakan persamaan $\lambda_{i}=\sum_{j=i}^{N} a_{i j} \frac{W_{i}}{W_{j}}$

b. Menghitung eigen vector. Untuk memperbaiki penilaian harus ditentukan aij untuk membandingkan objek ke-I dangan ke-j maka perbandingan kebalikannya harus segera ditentukan yaitu aij, dalam hal ini $a i j=\frac{1}{a i j}$. Dari matriks $\mathrm{A}=($ aij $)$ akan dapat ditentukan sebagai $w$ yang berlaku sebagai eigen vector. Untuk memperoleh nilai eigen vector dari setiap baris digunakan persamaan : $(E V)_{k}=\frac{1}{N} \sum_{j=1}^{N} \frac{a_{k j}}{\sum_{i=j}^{N} a_{i j}}$

c. W1, W2, .., Wn adalah besaran yang berlaku sebagi eigen vector. Akhrinya harga maksimum dari matriks dapat dihitung dengan persamaan $\lambda m a k s=\frac{1}{N} \sum_{i=1}^{N} \lambda i$

d. Melakukan pengujian konsistensi. Konsistensi dari penilaian dapat diamati dengan cara mengukur derajat konsistensi untuk memperoleh koefisien konsistensi (CI) dengan menggunakan persamaan : $C I=\frac{\lambda m a k s-n}{n-1}$

Nilai CI yang mendekati nol akan mempunyai tingkatan konsistensi yang baik.

e. Setelah mengetahui nilai koefisien konsistensi (CI), maka kita dapat menentukan konsistensi rasio dengan menggunakan persamaan : $C R=\frac{C I}{R I}$

RI adalah bilangan konsistensi random, dimana besarnya disesuaikan dengan ukuran matriks sesuai dengan ketentuan yang dipakai. Jika $\mathrm{CR}>0,1$ maka nilai matriks tersebut tidak konsisten dan harus direvisi, jika konsisten maka dilanjutkan.

7. Tahap 4, 5, 6 diulang untuk seluruh tingkat hirarki.

8. Menghitung vector eigen dari setiap matriks perbandingan berpasanga. Nilai vector eigen mendapatkan bobot setiap elemen. Langkah ini dilakukan untuk mensintesis judgment

\section{JMTSS}

dalam penentuan prioritas elemen-elemen pada tingkat terendah sampai pencapaian tujuan.

9. Memeriksa konsistensi hirarki (CRH) degnan cara mengalikan setiap nilai CI dengan nilai bobot prioritas hasilnya kemudian dibagi RI masing-masing sesuai ukuran matriks. Judgment dikatakan cukup konsisten jika nilai CI dan CRH tidak lebih dari $10 \%$.

\section{HASIL PENELITIAN}

Dari hasil pengumpulan data dari kuesioner langkah selanjutnya dilakukan pengolahan data untuk melakukan penentuan prioritas faktorfaktor yang mempengaruhi variabel-variabel penilaian kinerja karyawan terhadap masingmasing bagian/grade yaitu : Grade $1-4$, grade 5 - 7 dan grade 8 - 11 dengan menggunakan Analytic Hierarchy Process (AHP). Banyaknya keterlibatan pengambil keputusan dapat mengakibatkan timbulnya pendapat yang berbeda. Sedangkan dalam AHP hanya diperlukan satu keputusan. Oleh karena itu, untuk mengatasi keragaman pendapat yang ditimbulkan akibat banyaknya responde, maka dilakukan perhitungan melalui rata-rata geometrik (geometric mean). Perhitungan geometric mean ini merupakan ratarata geometri dari semua penilaian terhadap perbandingan berpasangan. Dari hasil perhitungan geometric mean ini akan diperoleh matrik berpasangan yang merupakan kesamaan pendapat dari para responden tentang kinerja penilaian yang diperbandingkan.

\section{Bagian / Grade 1 - 4}

Adapun langkah-langkah perhitungan dari AHP adalah :

1. Pembuatan matrik perbandingan berpasangan Setelah melakukan penyusunan hirarki, penjabaran selanjutnya adalah melakukan pola matrik merupakan dasar dari penyusunan dari pembuatan matriks berpasangan yang diisi berdasarkan hasil kuesioner. Pembuatan matriks sebanyak 1 matriks untuk struktur hirarki yaitu level 2 (kriteria) terdiri dari satu buah yang berordo 7 $\mathrm{x} 7$.

2. Mengitung Eigen Vector, Eigen Value, Konsistensi Indeks, dan konsistensi Indek Rasio pada setiap matrik perbandingan berpasangan.

Seluruh matriks perbandingan berpasangan harus terlebih dahulu diuji tingkat konsistensinya untuk memastikan bahwa penilaian tingkat kepentingan yang ada. Parameter yang digunakan dalam pengujian ini adalah Consistensy Ratio (CR). Sebuah matriks perbandingan berpasangan dikatakan konsisten apabila nilai CR-nya tidak melebihi 0,1 . Adapun nilai-nilai yang didefinisikan 
dalam perhitungan AHP [2] adalah sebagai berikut :
a. Eigen Vector (EV)
b. Eigen Value ( $\lambda$ maks)
c. Consistency Index (CI)
d. Consistency Ratio (CR)

Untuk lebih jelasnya contoh perhitungan untuk hirarki adalah sebagai berikut :

Perhitungan untuk level 2 (kriteria) terhadap level 1 (goal)

- Menjumlahkan bobot setiap kolom

$$
\text { Pengetahuan = } 1+1 / 1,67
$$$$
+1+1+1+1 / 1,67+1 / 3=5,531
$$

- Menghitung bobot normalisasi Pengetahuan $((1: 5,531)+(1,67: 7,269)+(1: 6,429)+($ $1: 7,759)+(1: 7,759)+(1,67: 9,67)+(3: 9$ )) $=0,190$

- $\quad$ Menghitung Eigen Value ( $\lambda$ maks) $\lambda$ maks $(5,531)(0,190)+(7,269)(0,135)+(6,4$ $29)(0,159)+(7,759)(0,147)+(7,759)($ $0,144)+(9,67)(0,106)+(9,00)(0,118$ $=7,399$

- Menghitung Consistency Index (CI) CImaks $=(\lambda$ maks $-\mathrm{n}) /(\mathrm{n}-1)=($ 7,399-7 $) /(7-1)=0,0665$

- Menghitung Consistency Ratio (CR) $\mathrm{CR}=$ CImaks / $1,32=0,050$ (konsistensi dapat diterima)

Ket : 1,32 didapat dari tabel random indeks

- Menghitung Konsistensi Hirarki, digunakan parameter Consistency Ratio of Hierarchy ( CRH ) suatu hirarki dinyatakan konsistensi apabila nilai CRH-nya tidak lebih dari 0,1 perhitungan $\mathrm{CRH}$ adalah sebagai berikut :

$$
\begin{aligned}
\mathrm{CRH}= & \mathrm{CIH} / \mathrm{RIH} \\
\mathrm{CIH}= & \sum(\mathrm{CI} \times \text { Bobot }) \\
= & 0,0665 \times(0,195 ; 0,135 ; \\
& 0,159 ; 0,147 ; 0,144 ; 0,106 ; \\
& 0,118) \\
= & 0,067 \\
\mathrm{RIH}= & \sum(\mathrm{CI} \times \text { Bobot }) \\
= & 1,32 \times(0,195 ; 0,135 ; 0,159 ; \\
& 0,147 ; 0,144 ; 0,106 ; 0,118) \\
= & 1,325 \\
\mathrm{CRH}= & \mathrm{CIH} / \mathrm{RIH} \\
= & 0,067 / 1,325 \\
= & 0,050
\end{aligned}
$$

Jadi hasil perhitungan diatas memberikan nilai rasio konsistensi hirarki ( $\mathrm{CRH}$ ) untuk tatanan hirarki penilaian kinerja bagian/grade $1-4$ sebesar 0,050. Berarti tatanan hirarki penilaian kinerja tersebut memenuhi atau konsisten yang ditetapkan yaitu lebih kecil dari 0,1.

\section{Bagian / Grade 5 - 7}

Adapun langkah-langkah perhitungan dari AHP adalah :

1. Pembuatan matriks perbandingan Berpasangan.

Setelah melakukan penyusunan hirarki, penjabaran selanjutnya adalah melakukan pola matriks merupakan dasar dari penyusunan dari pembuatan matriks berpasangan yang diisi berdasarkan hasil kuesioner. Pembuatan matriks sebanyak 1 matriks untuk struktur hirarki yaitu level 2 (kriteria) terdiri dari suatu buah yang berordo $8 \times 8$.

2. Menghitung Eigen Vektor, Eigen Value, Konsistensi Indeks, dan Konsistensi Indeks Rasio pada setiap matrik.

Seluruh matriks perbandingan berpasangan harus terlebih dahulu diuji tingkat konsistensinya untuk memastikan bahwa penilaian tingkat kepentingan yang ada. Parameter yang digunakan dalam pengujian ini adalah Consistency Ratio ( CR ). Sebuah matriks perbandingan berpasangan dikatakan konsisten apabila nilai CR-nya tidak melebihi 0,1. Adapun nilai-nilai yang didefinisikan dalam perhitungan AHP [2] adalah sebagai berikut :

a. Eigen Vector ( EV )

b. Eigen Value ( $\lambda$ maks )

c. Consistensy Index ( CI )

d. Consistency Ratio ( CR )

Untuk lebih jelasnya contoh perhitungan untuk hirarki adalah sebagai berikut :

Perhitungan untuk level 2 (kriteria) terhadap level 1 (goal)

- Menjumlahkan bobot setiap kolom Pengetahuan = $1+1 / 1,67+1+1 / 2,33+1+1 / 1,67+1 / 1,6$ $7+1 / 3=5,559$

- Menghitung bobot normalisasi

- Pengetahuan $((1: 5,559)+(1: 7,698)+(1: 7,028)$ $+(2,33: 7,847)+(1: 8,769)+(1,67: 12)+$ $(1,67: 10,663)+(3: 12,67))=0,1745$

- Menghitung Eigen Value ( $\lambda$ maks ) $\lambda$ maks $=$ $(5,559)(0,1745)+(7698)(0,1348)+(7$, $028)(0,1391)+(7,847)(0,1379)+$ $(8,769)(0,119)+(12)(0,084)+$ $(10,663)(0,111)+(12,67)(0,088)=$ 8,429

- $\quad$ Menghitung Consistency Index (CI)

$$
\begin{aligned}
\text { CImaks } & =(\lambda \text { maks }-\mathrm{n}) /(\mathrm{n}-1) \\
& =(8,429-8)-(8-1) \\
& =0,0613
\end{aligned}
$$

- Menghitung Consistency Ratio (CR) $\mathrm{CR}=0,0613 / 1,41=0,043$ (konsistensi dapat diterima) 
Ket : 1,41 didapat dari tabel random indeks.

- Menghitung Konsistensi Hirarki, digunakan parameter Consistensy Ratio of Hierarchy ( CRH ). Suatu hirarki dinyatakan konsisten apabila nilai CRH-nya tidak lebih dari 0,1 . Perhitungan $\mathrm{CRH}$ adalah sebagai berikut :

$$
\begin{aligned}
\mathrm{CRH}= & \mathrm{CIH} / \mathrm{RIH} \\
\mathrm{CIH}= & \sum(\mathrm{CI} \times \text { Bobot }) \\
= & 0,0613+(0,175 ; 0,135 ; 0,139 ; \\
& 0,138 ; 0,119 ; 0,0844 ; 0,111 ; \\
& 0,09) \\
= & 0,061 \\
\mathrm{RIH}= & \sum(\mathrm{RI} \times \text { Bobot }) \\
= & 1,41 \times(0,175 ; 0,135 ; 0,139 ; \\
& 0,138 ; 0,119 ; 0,0844 ; 0,111 ; \\
& 0,09) \\
= & 1,395 \\
\mathrm{CRH}= & \mathrm{CIH} / \mathrm{RIH} \\
= & 0,041 / 1,395 \\
= & 0,044
\end{aligned}
$$

Jadi hasil perhitungan diatas memberikan nilai rasio konsistensi hirarki ( $\mathrm{CRH}$ ) untuk tatanan hirarki penilaian kinerja bagian / grade 5-7 sebesar 0,044 berarti tatanan hirarki penilaian kinerja tersebut memenuhi atau konsistensi yang ditetapkan lebih kecil dari 0,1 .

\section{Bagian / Grade 8 - 11}

Adapun langkah-langkah perhitungan dari AHP adalah :

1. Pembuatan matriks perbandingan Berpasangan.

Setelah melakukan penyusunan hirarki, penjabaran selanjutnya adalah melakukan pola matriks merupakan dasar dari penyusunan dari pembuatan matriks berpasangan yang diisi berdasarkan hasil kuesioner. Pembuatan matriks sebanyak 1 matriks untuk struktur hirarki yaitu level 2 (kriteria) terdiri dari suatu buah yang berordo $8 \times 8$.

2. Menghitung Eigen Vektor, Eigen Value, Konsistensi Indeks, dan Konsistensi Indeks Rasio pada setiap matriks perbandignan berpasangan.

Seluruh matriks perbandingan berpasangan harus terlebih dahulu diuji tingkat konsistensinya untuk memastikan bahwa penilaian tingkat kepentingan yang ada. Parameter yang digunakan dalam pengujian ini adalah Consistency Ratio ( CR ). Sebuah matriks perbandingan berpasangan dikatakan konsisten apabila nilai CR-nya tidak melebihi 0,1. Adapun nilai-nilai yang didefinisikan dalam perhitungan AHP [2] adalah sebagai berikut :

a. Eigen Vector ( EV ) b. Eigen Value ( $\lambda$ maks $)$

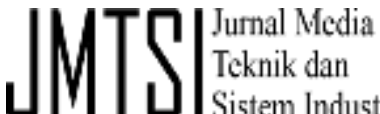

c. Consistensy Index ( CI )

d. Consistency Ratio ( CR )

Untuk lebih jelasnya contoh perhitungan untuk hirarki adalah sebagai berikut :

Perhitungan untuk level 2 (kriteria) terhadap level 1 (goal)

- Menjumlahkan bobot setiap kolom

Pengetahuan

$1+1+1+1+1+1 / 1,67+1 / 1,67+1 / 2,33$

$=6,627$

- Menghitung bobot normalisasi

Pengetahuan

$((1: 6,627)+(1: 7,028)+(1: 7,028)+(1: 6$

$, 226)+(1: 8,769)+(1,67: 10,67)+(1,67$ :

$14)+(2,33: 12,66))=0,146$

- $\quad$ Menghitung Eigen Value ( $\lambda$ maks) $\lambda$ maks $=$ $(6,627)(0,146)+(7,028)(0,1406)+(7$, $028)(0,1414)+(6,226)(0,1558)+(8,76$ $9)(0,11)+(10,67)(0,0934)+(14)(0,10$ $5)+(12,67)(0,153)=8,299$

- Menghitung Consistency Index (CI)

CImaks $=(\lambda$ maks $-\mathrm{n}) /(\mathrm{n}-1)$

$$
=(8,299-8)-(8-1)
$$

$$
=0,043
$$

- Menghitung Consistency Ratio (CR) $\mathrm{CR}=0,043 / 1,41=0,031$ (konsistensi dapat diterima)

Ket : 1,41 didapat dari able random indeks.

- Menghitung Konsistensi Hirarki, digunakan parameter Consistensy Ratio of Hierarchy ( CRH ). Suatu hirarki dinyatakan konsisten apabila nilai CRH-nya tidak lebih dari 0,1 . Perhitungan $\mathrm{CRH}$ adalah sebagai berikut :

$$
\begin{aligned}
\mathrm{CRH}= & \mathrm{CIH} / \mathrm{RIH} \\
\mathrm{CIH}= & \sum(\mathrm{CI} \times \text { Bobot }) \\
= & 0,043+(0,146 ; 0,1406 ; 0,1414 ; \\
& 0,1558 ; 0,11 ; 0,0934 ; 0,105 ; \\
& 0,153) \\
= & 0,045 \\
\mathrm{RIH}= & \sum(\mathrm{RI} \times \text { Bobot }) \\
= & 1,41 \times(0,146 ; 0,1406 ; 0,1414 ; \\
& 0,15588 ; 0,11 ; 0,0934 ; \\
& 0,105 ; 0,153) \\
= & 1,474 \\
\mathrm{CRH}= & \mathrm{CIH} / \mathrm{RIH} \\
= & 0,045 / 1,474 \\
= & 0,031
\end{aligned}
$$

Jadi hasil perhitungan diatas memberikan nilai rasio konsistensi hirarki ( $\mathrm{CRH}$ ) untuk tatanan hirarki penilaian kinerja bagian / grade $8-11$ sebesar 0,031 berarti tatanan hirarki penilaian kinerja tersebut memenuhi atau konsistensi yang ditetapkan lebih kecil dari 0,1. 


\section{PEMBAHASAN}

Analisis Proses Pembentukan Hirarki

Menstukturkan persoalan dalam bentuk hirarki merupakan langkah awal dalam penerapan metoda AHP. Hal ini disebabkan karena proses pembentukan hirarki sangat berpengaruh terhadap hasil yang akan dicapai. Struktur hirarki yang baik dan lengkap dapat mencerminkan permasalahan yang dihadapi yang dapat mencerminkan permasalahan yang akan dipecahkan, yang tidak dapat diketahui secara kuantitatif melainkan dapat diketahui secara kualitatif melalui bobot yang telah ditentukan.Pembobotan masing - masing criteria dilakukan dengan menggunakan Analytic Hierarchy Process ( AHP ).

Dari hasil perhitungan yang telah dilakukan pada bab sebelumnya diperoleh hasil yang menunjukan besarnya intensitas criteria penilaian secara berurutan sebagai berikut :

TABEL I

INTENSITAS KONTRIBUSI KRITERIA PENILAIAN

\begin{tabular}{|l|l|}
\hline $\begin{array}{l}\text { Kriteria } \\
\text { Penilaian }\end{array}$ & $\begin{array}{l}\text { Intensitas } \\
\text { Kontribusi }\end{array}$ \\
\hline Grade $1-4$ & 0,999 \\
\hline Grade $5-7$ & 0,989 \\
\hline Grade $8-11$ & 1,037 \\
\hline
\end{tabular}

Intensitas kontribusi kriteria penilaian dapat digunakan untuk menyusun prioritas pengalokasian sumber daya dalam upaya untuk meningkatkan kemampuan karyawan. Dari hasil yang diolah sebelumnya, menunjukan bahwa intensitas kontribusi grade $8-11$ mendapat prioritas yang paling utama dalam hal ini perusahan harus melakukan upaya - upaya dalam meningkatkan kemampuan / potensi yang dimiliki oleh para manajer / grade 8-11 sebagai pemimpin.

Dalam membuat penetapan jumlah dan jenis elemen - elemen merupakan suatu kreatifitas yang sangat tergantung kepada keputusan peneliti atas pemahamanya terhadap permasalahan yang dihadapi yang dapat mencerminkan permasalahan yang akan diselesaikan.

Level pertama menjelaskan tentang tujuan atau sasaran utama yang ingin dicapai dalam penelitian. Dalam penelitian ini memiliki tujuan yaitu melakukan prioritas terhadap faktor - factor yang mempengaruhi penilaian kinerja karyawan.level kedua struktur hirarki terdapat criteria yaitu pengetahuan, tanggung jawab, inisiatif, disiplin, kejujuran, kerjasama, loyalitas dan kepemimpinan.

\section{Analisa Hasil Penilaian terhadap Kriteria}

Berdasarkan hasil pengolahan data AHP. Pada bab IV, maka pada tabel 5.2.1 untuk penilaian kinerja grade $1-4$, tabel 5.2.2 untuk penilaian kinerja grade 5-7 dan tabel 5.2.3 untuk penilaian grade $8-11$ dapat dilihat bobot prioritas dari yang terbesar sampai yang terkecil sebagai berikut :

TABEL II

BOBOT PRIORITAS KRITERIA UNTUK PENILAIAN KINERJA GRADE 1 - 4

\begin{tabular}{|l|l|l|}
\hline No & Kriteria & Bobot \\
\hline 1 & Pengetahuan & 0,190 \\
\hline 2 & Inisiatif & 0,159 \\
\hline 3 & Disiplin & 0,147 \\
\hline 4 & Kejujuran dan Usaha & 0,144 \\
\hline 5 & Tanggung jawab & 0,135 \\
\hline 6 & Loyalitas & 0,118 \\
\hline 7 & Kerjasama & 0,106 \\
\hline
\end{tabular}

- $\quad$ Analisa Penilaian kinerja untuk grade $1-4$ Berdasarkan tabel pembobotan kriteria untuk penilaian kinerja operasional / garde $1-4$ diperoleh hasil bahwa tingkat kepentingan pengetahuana $=19,0 \%$, Inisiatif $=15,9 \%$, Disiplin $=14,7 \%$, Kejujuran dan Uasaha $=$ $14,4 \%$, Tanggung jawab $=13,5 \%$, Loyalitas $=11,8 \%$, dan kerjasama $=10,6 \%$.Ini menujukan bahwa dalam penilaian kinerja untuk bagian operasional / grade 1-4, tingkat kepentingan pengetahuan lebih tinggi dari pada keriteria - kriteria yang lainnya.Berdasarkan hasil diatas terlihat bahwa pengetahuan merupakan kriteria yang paling dominan dengan tingkat kepentingan yang paling besar terhadap penilaian kinerja. Hal ini terjadi karena untuk bagian operasional / grade $1-4$, pengetahuan pekerjaan merupakan hal mutlak diperlukan dalam melakukan kegiatan produksi.seseorang tidak mungkin melakukan pekerjaan dengan baik tanpa mengetahui pekerjaan yang akan dilakukannya.

TABEL III

BOBOT PRIORITAS KRITERIA UNTUK PENILAIAN KINERJA GRADE 5-7

\begin{tabular}{|l|l|l|}
\hline No & \multicolumn{1}{|c|}{ Kriteria } & Bobot \\
\hline 1 & Pengetahuan & 0,175 \\
\hline 2 & Inisiatif & 0,139 \\
\hline 3 & Disiplin & 0,138 \\
\hline 4 & Tanggung jawab & 0,135 \\
\hline 5 & Kejujuran dan Usaha & 0,119 \\
\hline 6 & Loyalitas & 0,111 \\
\hline 7 & Kepemimpinan & 0,088 \\
\hline 8 & Kerjasama & 0,084 \\
\hline
\end{tabular}


- Analisa Penilaian Kinerja Untuk Grade 5 - 7 Berdasarkan tabel pembobotan kriteria untuk penilaian kinerja Administrasi / garde 5-7 diperoleh hasil bahwa tingkat kepentingan pengetahuana $=17,5 \%$, Inisiatif $=13,9 \%$, Disiplin $=13,8 \%$, Kejujuran dan Uasaha $=$ $11,9 \%$, Tanggung jawab $=13,5 \%$, Loyalitas $=11,1 \%$, kepemimpinan $=8,8 \%$, dan kerjasama $=8,4 \%$. Ini menujukan bahwa dalam penilaian kinerja untuk bagian Administrasi / grade 5- 7, tingkat kepentingan pengetahuan dari pada kriteria - kriteria yang lainnya

Berdasarkan hasil diatas terlihat bahwa pengetahuan merupakan kriteria yang paling dominan dengan tingkat kepentingan yang paling besar terhadap p[enilaian kinerja. Hal ini terjadi karena untuk bagian administrasi / grade 5-7, pengetahuan pekerjaan merupakan hal mutlak diperlukan dalam melakukan kegiatan .seseorang tidak mungkin melakukan pekerjaan dengan baik tanpa mengetahui pekerjaan yang akan dilakukannya.

TABEL IV

BOBOT PRIORITAS KRITERIA UNTUK PENILAIAN KINERJA GRADE 8 - 11

\begin{tabular}{|l|l|l|}
\hline No & \multicolumn{1}{|c|}{ Kriteria } & \multicolumn{1}{c|}{ Bobot } \\
\hline 1 & Kepemimpinan & 0,156 \\
\hline 2 & Disiplin & 0,155 \\
\hline 3 & Pengetahuan & 0,146 \\
\hline 4 & Inisiatif & 0,141 \\
\hline 5 & Tanggung jawab & 0,140 \\
\hline 6 & Loyalitas & 0,105 \\
\hline 7 & Kejujuran dan Usaha & 0,101 \\
\hline 8 & Kerjasama & 0,093 \\
\hline
\end{tabular}

- Analisa Penilain kinerja Untuk Grade 8 - 11 Berdasarkan tabel pembobotan kriteria untuk penilaian kinerja Manajerial / garde $8-11$ diperoleh hasil bahwa tingkat kepentingan Kepemimpinan $=15,6 \%$, Disiplin $=15,5 \%$, pengetahuana $=14,6 \%$, Inisiatif $=14,1 \%$, Tanggung jawab $=14,0 \%$, Loyalitas $=10,5$ $\%$, Kejujuran dan Uasaha $=10,1 \%$, dan kerjasama $=9,3 \%$.Ini menujukan bahwa dalam penilaian kinerja untuk bagian Manajerial / grade 8 - 11, tingkat kepentingan Kepemimpinan lebih bersar dibandingkan dengan kriteria - kriteria yang lainnya.

Berdasarkan hasil diatas terlihat bahwa Kepemimpinan merupakan kriteria yang paling dominan dengan tingkat kepentingan yang paling besar terhadap penilaian kinerja. Hal ini terjadi karena untuk bagian

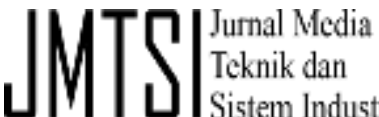

Manajerial / grade 8 - 11, semakin dibutuhkan peranannya oleh perusahaan sehingga Kepemimpinan merupakan hal mutlak diperlukan dalam melakukan kegiatannya. Sedangkan pengetahuan pekerjaan memiliki tingkat kepentingan ketiga terhadap penilaian kinerja. Hal ini karena untuk bagian manajerial, pengetahuan pekerjaan dianggap sudah mencukupi sehingga tidak dianggap begitu penting selain itu juga seorang manajer biasanya lebih terfokus pada kegiatan mengatur bawahan dan merencanakan kegiatan sehingga baginya pengetahuan pekerjaan tidak begitu penting karena dapat didelegasikan kepada bawahan.

\section{Analisa Hasil Pengujian Konsistensi \\ Suatu hasil penelitian matriks perbandingan berpasangan dikatakan} konsisten apabila nilai rasio konsistennya (CR) tidak lebih dari 10\%, begitu juga untuk pengujian konsistensi hirarkinya (CRH) dikatakan konsisten jika tidak lebih dari $10 \%$. Rasio kosistensi (CR) diperoleh dengan membandingkan konsistensi hirarki terhadap konsistensi indeks untuk ordo matriks perbandingan berpasangan yang sesuai. Dari hasil perhitungan pengujian konsistensi untuk setiap matriks perbandingan berpasangan,nilai yang diperoleh untuk masing - masing matriks tidak lebih dari $10 \%$,sehingga dapat dikatakan bahwa masing - masing matriks tersebut konsisten.

Rasio konsistensi hirarki ( CRH ) diperoleh dengan membandingkan konsistensi hirarki terhadap konsistensi indeks dari matriks perbandingan berpasangan dengan konsistensi hirarki terdapat indeks random dari matriks perbandingan berpasangan. Level hirarki diuji tingkat kosistensinya terdahap level dibawahnya dan selalu dilakukan berpasangan, sehingga hasil pengujian konsistensinya menujukan konsistensi antara dua level hirarki yang berdekatan.

Dari hasil perhitungan yang dilakukan pada bab sebelumnya secar manual maka didapatkan nilai CRH untuk semua perbandingan memiliki nilai dibawah 0,1 yaitu sebesar 0,050 untuk penilaian kinerja grade $1-4,0,044$ untuk penilaian kierja grade $5-7$ dan 0,033 untuk penilaia kinerja grade 8 - 11.dengan demikian pengujian terhadap struktur hirarki menujukan bahwa struktur hirarki yang dibuat konsisten.

Karena nilai semua matriks perbandingan berpasangan dan struktur hirarki yang konsisten, maka proses penentuasn perioritas dapat dilakukan dan akan memberikan proses yang optimum. Jika terdapat satu matriks perbandingan 
berpasangan dalam struktur hirarki belum konsisten maka dalam memberikan prioritas tidak akan memberikan hasil yang optimal.

\section{KESIMPULAN}

Dari hasil pengumpulan dan pengolahan data serta analisis dan pembahasan serta perumusan masalah yang dilakukan terhadap penilaian kinerja karyawan maka dapat disimpulkan bahwa dalam melakukan prioritas mengenai factorfactor yang mempengaruhi variable penilaian untuk masing-masing bagian / garde $1-4$, grade $5-7$ dan grdae $8-11$ (dapat dilihat dari pengolahan data).

Metode yang digunakan dalam melakukan prioritas tersebut adalah dengan menggunakan model Analytical Hierarchi Process (AHP) dimana kita membentuk suatu struktur hirarki yang berkenaan dengan tujuan tersebut.

Struktur hirarki yang dibentuk terdiri dari dua level yaitu tujuan, kriteria dan sub kriteria. Kriteria yang digunakan dalam struktur hirarki adalah yang dapat mempersentasikan tujuan yang ingin dicapai yaitu :
a. Pengetahuan
b. Tanggung jawab
c. Disiplin
d. Inisiatif
e. Kejujuran dan Usaha
f. Loyalitas
g. Kepemimpinana

Sedangkan sub kriteria adalah faktor-faktor yang mempengaruhi kriteria tersebut.

Rasio konsistensi (CR) untuk setiap matrik dan rasio konsistensi hirarki (CRH) untuk setiap level yang didapat tidak lebih dari $10 \%$ atau dengan kata lain, semua matrik perbandingan berpasangan semua level tersebut konsisten.

Adapun urutan prioritas yang didapat untuk masing - masing bagian / grade adalah sebagai berikut :

- Untuk bagian oprasional / grade $1-4$

lebih mempriioritaskan pengetahuan

dengan bobot 0,190.

- Untuk bagian administrasi / grade 5 -

7 lebih memprioritaskan pengetahuan dengan bobot 0,175 .

- Untuk bagian manajerial / grade 8 11 lebih memprioritaskan kepemimpinan dengan bobot 0,156 .

Dengan demikian diharapkan perusahaan dapat mengetahui faktor-faktor yang harus diprioritaskan dari tiap - tiap bagian / grade yang akan dinilai.sehingga dengan adanya tingkat prioritas, karyawan karyawan dapat meningkatkan kinerjanya yang sesuai dengan harapan perusahaan.

\section{REFERENSI}

[1] Kadarsah Suryadi., M. Ali Ramdhani, (2002), "SPK Suatu Wacana Struktural Idealisasi Dan Implementasi Konsep Pengambilan Keputusan", PT. Remaja Rosdakarya Offset, Bandung.

[2] Saaty, Thomas L. (2001) : "The Analytic Hierarchy Process: Planning, Priority Setting. 